\title{
An Optimization Study for Transesterification of Palm Oil using Response Surface Methodology (RSM)
}

(Suatu Kajian Pengoptimuman bagi Transesterifikasi Minyak Sawit

Menggunakan Kaedah Gerak Balas Permukaan (RSM))

Y.C. WONG, Y.P. TAN*, Y.H.TAUFIQ-YAP \& I. RAMLI

\begin{abstract}
Biodiesel was produced via transesterification of palm oil with methanol in the presence of $\mathrm{CaO}-\mathrm{Nb}_{2} \mathrm{O}_{5}$ mixed oxide catalyst. Response surface methodology (RSM) with central composite design (CCD) was performed to determine the optimum operating conditions and to optimize the biodiesel yield. In this study, the reaction variables being optimized were reaction time, catalyst loading and methanol to oil molar ratio. From the analysis of variance (ANOVA), the most influential parameter on biodiesel production was reaction time. The predicted yield was found in good agreement with the experimental value, with $R^{2}=0.9902$. The optimum biodiesel yield of $97.67 \%$ was achieved at $2.67 \mathrm{~h}$ reaction time, with $3.60 \mathrm{wt}$. \% of catalyst and with methanol to oil molar ratio of 13.04. The high biodiesel yield can be correlated to the synergic effect of basicity between the metallic ions of $\mathrm{CaO}-\mathrm{Nb}_{2} \mathrm{O}_{5}$ shown in the physicochemical analysis.
\end{abstract}

Keywords: Biodiesel; optimization; palm oil; RSM; transesterification

ABSTRAK

Biodiesel telah dihasilkan melalui transesterifikasi minyak sawit dengan metanol dan kehadiran pemangkin oksida bercampur CaO- $\mathrm{Nb}_{2} \mathrm{O}_{5}$. Kaedah gerak balas permukaan (RSM) dengan pusat reka bentuk komposit (CCD) telah dijalankan untuk menentukan keadaan operasi optimum dan mengoptimumkan hasil biodiesel. Dalam kajian ini, pemboleh ubah tindak balas yang dioptimumkan ialah masa tindak balas, pembebanan pemangkin dan nisbah molar metanol kepada minyak. Daripada analisis varians (ANOVA), parameter yang paling berpengaruh dalam penghasilan biodiesel adalah masa tindak balas. Hasil yang diramalkan adalah bersamaan dengan nilai eksperimen, dengan $R^{2}=0.9902$. Hasil optimum biodiesel sebanyak $97.67 \%$ dicapai pada masa tindak balas $2.67 \mathrm{~h}$ dengan $3.60 \mathrm{wt} . \%$ pemangkin dan nisbah molar metanol kepada minyak 13.04. Hasil biodiesel yang tinggi boleh dikaitkan dengan kesan sinergi kebesan antara ion logam $\mathrm{CaO}-\mathrm{Nb}_{2} \mathrm{O}_{5}$ seperti yang ditunjukkan dalam analisis fisikokimia.

Kata kunci: Biodiesel; minyak sawit; pengoptimuman; RSM; transesterikasi

\section{INTRODUCTION}

Recently, biodiesel has been considered as a promising potential substitute for conventional diesel-based petroleum. Biodiesel is the mixture of mono alkyl esters that can be continuously derived from vegetable oils or animal fats and therefore it is terms as renewable energy (Lin et al. 2006). In term of properties and performance, biodiesel possesses many advantages such as high flash point, high cetane number, high lubricity, biodegradable and lower carbon monoxide emission profile compared to conventional fossil fuel (Dorado et al. 2003). Currently, biodiesel was produced via transesterification process where hydroxyl group of alcohol reacts with carboxylic group of triglycerides to form ester.

Biodiesel produced in industry nowadays is via homogeneous base-catalyzed transesterification. The common alkaline homogeneous catalysts used are sodium hydroxide and potassium hydroxide (Alamu et al. 2008; Dmytryshyn et al. 2004). Alkaline homogeneous catalysts are preferred as they proceed about 4000 times faster than the acid catalyzed transesterification (Fukuda et al. 2001). Besides, these alkaline homogeneous catalysts are cheaper in cost and give higher yields at modest operation conditions (Dennis Leung et al. 2010). However, the biodiesel and glycerol produced from this transesterification process need to be purified and washed with lots of hot water to remove any trace of catalysts and unreacted alcohol (Sharma et al. 2008).

The emergence of solid catalysts provides an alternative to biodiesel industry. Solid catalysts greatly simplified the downstream purification of biodiesel where the catalysts can be separated physically and no further purification and washing are required for the end product (biodiesel and glycerol) (Helwani et al. 2009). Similar to homogeneous catalysts, solid basic catalysts are more active than solid acid catalysts (Antunes et al. 2008; Arzamendi et al. 2007). $\mathrm{CaO}$ is a solid basic catalyst that shows a promising result in transesterification process with oil conversion of more than $95 \%$ (Liu et al. 2008). Although good performance in transesterification, $\mathrm{CaO}$ 
tends to leach out into the reaction medium and thus reduces its reusability (Kouzu et al. 2009; Sharma et al. 2011). Therefore, $\mathrm{CaO}$-based mixed oxides are investigated to improve the performance of bulk $\mathrm{CaO}$.

Optimization study for biodiesel production is crucial to assist researchers to develop a more efficient and cost-effective system in biodiesel industry. Generally, the reaction parameters such as reaction time, reaction temperature, catalysts loading and methanol to oil molar ratio, are being manipulated to optimize the biodiesel yield. Previously, optimization study was done with the variation of one parameter at a time (one-variable-at-atime technique) which is tedious and time consuming (Bezerra et al. 2008). Besides, this technique does not show interactive effects among the reaction variables and overall effects of the variable (Bas \& Boyacl 2007). Development of response surface methodology (RSM) had simplified the optimization study where multi-parameters can be studied simultaneously. By establishing threedimensional plot from the experimental data, the overall behavior of the reaction system can be easily understood and the interactions between reaction variables would be more visible.

In this study, the main focus is optimization of the reaction conditions for the production of biodiesel from palm oil using $\mathrm{CaO}-\mathrm{Nb}_{2} \mathrm{O}_{5}$ mixed oxide. The effects of reaction variables (reaction time, catalyst loading and methanol to oil molar ratio) were studied simultaneously on the biodiesel yield using response surface methodology with central composite design (CCD). The statistical model developed was used for prediction and optimization of biodiesel yield.

\section{EXPERIMENTAL}

\section{CHEMICALS AND CATALYST PREPARATION}

Palm oil was provided by IOI Group and was pre-melted at $50-60^{\circ} \mathrm{C}$ before transesterification process. Methanol (99.5\%) was purchased from Merck while the internal standard (methyl heptadecanoate) and standard references were purchased from Sigma-Aldrich. Calcium oxide $(99.9 \%$, Aldrich) and niobium oxide $(99.9 \%$, Alfa Aesar) were used for samples preparation. All the metal oxides were preheated at $300^{\circ} \mathrm{C}$ for $2 \mathrm{~h}$ before use.

Calcium and niobium $\left(\mathrm{CaO}-\mathrm{Nb}_{2} \mathrm{O}_{5}\right)$ mixed oxides with weight ratio of $\mathrm{CaO}: \mathrm{Nb}_{2} \mathrm{O}_{5}=3: 7$ was prepared by using conventional solid state method (West 1999; Wong et al. 2014) where an appropriate amount of calcium and niobium oxides were mixed and ground in agate mortar in the present of acetone. The mixed oxide was then calcined in air at $600^{\circ} \mathrm{C}$ for $5 \mathrm{~h}$.

\section{CATALYSTS CHARACTERIZATION}

The powder X-ray diffraction (XRD) analysis was performed by using a Shimadzu diffractometer model XRD-6000 which was equipped with a diffracted-beam graphite monochromator. The XRD pattern was generated from powder sample after $\mathrm{Cu}-\mathrm{K} \alpha$ radiation scans over a scanning range of 10 to $60^{\circ}$. Elemental compositions of the catalyst was examined by using energy dispersive fluorescence (XRF) (EDX-720). Thermal activities of the samples were determined by using thermogravimetric analysis (TGA) where the weight loss as a function of temperature was examined. The experiment was performed using Mettler Toledo Star SW 7.01 at the temperature range of 50 to $1000^{\circ} \mathrm{C}$ under dry air flow.

The total surface area of the catalysts was evaluated by Brunauer-Emmett-Teller (BET) method using $\mathrm{N}_{2}$ adsorption-desorption at $-196^{\circ} \mathrm{C}$. The analysis was carried out by Quantachrome Autosorb 1. The basicity strength of the catalysts were determined by temperature-programmed desorption using $\mathrm{CO}_{2}$ as probe molecules (TPD- $\mathrm{CO}_{2}$ ). TPD-CO $\mathrm{CO}_{2}$ experiment was carried out by Thermo Finnigan TPDRO 1100 equipped with a thermal conductivity detector.

\section{TRANSESTERIFICATION PROCESS}

The catalytic activity was studied by reflux method which equipped with reflux condenser and magnetic stirrer. $10 \mathrm{~g}$ of palm oil, appropriate volume of methanol and certain amount of catalyst were measured into a $100 \mathrm{~mL}$ twonecked flask. The mixture was then refluxed at $65^{\circ} \mathrm{C}$ for certain period as generated by software. After reaction, the catalyst was separated from glycerol and methyl esters phase by centrifuge and the reaction product was loaded into rotary evaporator to recover the excess methanol. Then, the glycerol and methyl ester phase were separated by using separating funnel.

The biodiesel yield was determined by gas chromatography GC-14B (model Shimadzu) equipped with a flame ionization detector (FID) and a capillary column (RTX-65, $30 \mathrm{~m} \times$ id $0.25 \mathrm{~mm}$ ). In this study, helium was used as the carrier gas while methyl heptadecanoate was used as internal standard. Example of gas chromatogram obtained was depicted in Figure 1. The content of methyl esters were calculated according to European regulated procedure EN14103. Leaching of calcium (Ca) and niobium $(\mathrm{Nb})$ group in the produced biodiesel was evaluated by using atomic absorption spectrometer, AAS (SOLAAR S Series, Thermo Scientific).

\section{DESIGN OF EXPERIMENTS}

Response surface methodology (RSM) with central composite design (CCD) was applied to optimize the biodiesel production from palm oil. In this study, three independent parameters were evaluated which were reaction time, catalysts loading and methanol to oil molar ratio whilst the dependent variable was fatty acid methyl esters (FAME) yield or biodiesel yield. Reaction temperature was not selected as studied parameter due to small temperature range was hardly to be controlled. The range and levels of the independent variables for transesterification process was shown in Table 1. Therefore, 

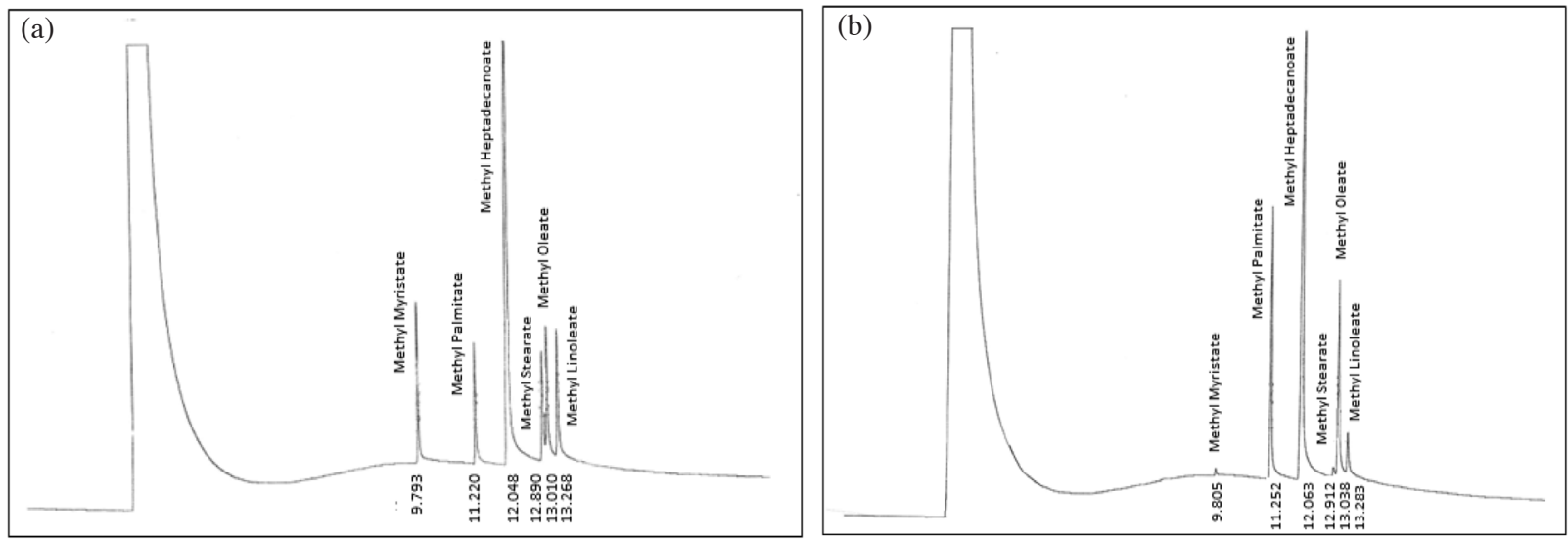

FIGURE 1. Gas chromatogram of (a) standard methyl esters and (b) experimental biodiesel product

20 sets of experiments were generated which including the $2^{3}$ factorial experiments, 6 axial points and 6 replicates of center points.

The center points are made up of all variables at zero level which are crucial in determination of experimental error and the reproducibility of the data. On the other hand, combination of variables consisting of one at its lowest (-a) level or highest (a) level with other variables at zero level constitutes the axial points. $a$ is the distance of the axial point from center and makes the design rotatable and is calculated by $\mathrm{a}=2^{n / 4}$, where $n$ is the factor numbers (in this study, three factors are being evaluated, so a is equal to 1.68$)$.

Each response obtained from the transesterification process was used to develop a mathematical model that correlates the biodiesel yield to the independent reaction variables via second-order polynomial equation as given below (Montgomery 2001):

$$
Y=b_{0}+\sum_{i=1}^{n} b_{i} x_{i}+\sum_{i=1}^{n} b_{i i} x_{i}^{2}+\sum_{i=1}^{n-1} \sum_{j=i+1}^{n} b_{i j} x_{i} x_{j}
$$

where $Y$ is the predicted FAME yield, $b_{o}$ is the constant coefficient, $b_{\mathrm{i}}$ is the linear coefficients, $b_{i j}$ is the interaction coefficients, $b_{i i}$ is the quadratic coefficients and $x_{i}, x_{j}$ are the coded values of the experimental variables.

\section{MODEL FITTING AND STATISTICAL ANALYSIS}

Design Expert software version 6.0.6 (STAT-EASE Inc., Minneapolis, USA) was employed for regression analysis of the experimental data to fit the equations. The quality of the developed model can be determined from the value of correlation $\left(\mathrm{R}^{2}\right)$ while evaluation of the statistical significance of the equations developed can be determined by using an analysis of variance (ANOVA).

\section{RESULTS AND DISCUSSION}

\section{DEVELOPMENT OF REGRESSION MODEL}

The complete design matrix of the experiments coupled with the experimental yield and predicted yield was shown in Table 2. From the table, it can be seen that the biodiesel yield obtained was in the range of 3.20 to $97.60 \%$. The center point (run 15-20) was used to determine the experimental error (pure error) and the reproducibility of the data.

The RSM software will generate a series of models (linear, two factor interaction (2FI), quadratic and cubic polynomial) that fitted to the response as well as suggest the best fitted model as shown in Table 3. According to the sequential model sum of square, the best model to fit the response was quadratic model due to its highest order polynomial with significance of additional terms and the model was not aliased. The final equation in terms of coded factor for the biodiesel production was shown as:

$$
\begin{aligned}
Y= & 94.71+18.05 \mathrm{~A}+2.33 \mathrm{~B}+6.26 \mathrm{C} \\
& -21.51 \mathrm{~A}^{2}-2.47 \mathrm{~B}^{2}-8.43 \mathrm{C}^{2} \\
& -9.38 \mathrm{AB}+1.50 \mathrm{AC}+3.05 \mathrm{BC},
\end{aligned}
$$

where $\mathrm{Y}$ is the FAME yield whereas the coded terms A, B, C represent reaction time, catalyst loading and methanol to oil

TABLE 1. Levels, real and coded experimental independent variables for transesterification process

\begin{tabular}{lccccccc}
\hline \multirow{2}{*}{ Variables } & \multirow{2}{*}{ Coding } & \multirow{2}{*}{ Unit } & \multicolumn{6}{c}{ Levels } \\
\cline { 4 - 8 } & & & $-\alpha$ & -1 & 0 & 1 & $\alpha$ \\
\hline Reaction time & $\mathrm{A}$ & $\mathrm{h}$ & 0 & 1 & 2 & 3 & 4 \\
Catalyst loading & $\mathrm{B}$ & wt. \% & 1 & 2 & 3 & 4 & 5 \\
Methanol/oil ratio & $\mathrm{C}$ & $\mathrm{mol} / \mathrm{mol}$ & 6 & 9 & 12 & 15 & 18 \\
\hline
\end{tabular}


TABLE 2. Design matrix of experiments and their respective experimental yield and predicted yield

\begin{tabular}{|c|c|c|c|c|c|}
\hline Run & $\begin{array}{l}\text { A:Reaction } \\
\text { time } \\
\text { (h) }\end{array}$ & $\begin{array}{l}\text { B:Catalyst } \\
\text { loading } \\
\text { (wt. \%) }\end{array}$ & $\begin{array}{c}\text { C:Methanol to oil } \\
\text { molar ratio } \\
(\mathrm{mol} / \mathrm{mol})\end{array}$ & $\begin{array}{c}\text { Experimental } \\
\text { yield } \\
(\%)\end{array}$ & $\begin{array}{l}\text { Predicted } \\
\text { yield } \\
(\%)\end{array}$ \\
\hline 1 & 1.00 & 2.00 & 9.00 & 33.50 & 30.93 \\
\hline 2 & 3.00 & 2.00 & 9.00 & 81.40 & 82.78 \\
\hline 3 & 1.00 & 4.00 & 9.00 & 48.40 & 48.25 \\
\hline 4 & 3.00 & 4.00 & 9.00 & 67.20 & 62.59 \\
\hline 5 & 1.00 & 2.00 & 15.00 & 30.50 & 34.34 \\
\hline 6 & 3.00 & 2.00 & 15.00 & 92.80 & 92.19 \\
\hline 7 & 1.00 & 4.00 & 15.00 & 66.00 & 63.86 \\
\hline 8 & 3.00 & 4.00 & 15.00 & 82.40 & 84.20 \\
\hline 9 & 0.32 & 3.00 & 12.00 & 3.20 & 3.44 \\
\hline 10 & 3.68 & 3.00 & 12.00 & 63.30 & 64.14 \\
\hline 11 & 2.00 & 1.32 & 12.00 & 85.30 & 83.72 \\
\hline 12 & 2.00 & 4.68 & 12.00 & 88.90 & 91.57 \\
\hline 13 & 2.00 & 3.00 & 6.95 & 57.10 & 60.27 \\
\hline 14 & 2.00 & 3.00 & 17.05 & 83.40 & 81.31 \\
\hline 15 & 2.00 & 3.00 & 12.00 & 88.60 & 94.79 \\
\hline 16 & 2.00 & 3.00 & 12.00 & 97.60 & 94.79 \\
\hline 17 & 2.00 & 3.00 & 12.00 & 95.60 & 94.79 \\
\hline 18 & 2.00 & 3.00 & 12.00 & 94.30 & 94.79 \\
\hline 19 & 2.00 & 3.00 & 12.00 & 96.10 & 94.62 \\
\hline 20 & 2.00 & 3.00 & 12.00 & 96.40 & 94.62 \\
\hline
\end{tabular}

TABLE 3. Sequential model sum of squares

\begin{tabular}{|c|c|c|c|c|c|c|}
\hline Source & Sum of squares & Degree of freedom & Mean of square & F-value & Prob $>$ F & \\
\hline Mean & 105415.20 & 1 & 105415.20 & & & \\
\hline Block & 10.50 & 1 & 10.50 & & & \\
\hline Linear & 5057.06 & 3 & 1685.69 & 3.10 & 0.0586 & \\
\hline $2 \mathrm{FI}$ & 795.55 & 3 & 265.18 & 0.43 & 0.7339 & \\
\hline Quadratic & 7234.31 & 3 & 2411.44 & 166.97 & $<0.0001$ & Suggested \\
\hline Cubic & 74.58 & 4 & 18.65 & 1.68 & 0.2887 & Aliased \\
\hline Residual & 55.40 & 5 & 11.08 & & & \\
\hline Total & 118642.60 & 20 & 2932.13 & & & \\
\hline
\end{tabular}

molar ratio, respectively. Positive sign in front of the terms indicates synergic effect while negative sign indicates antagonistic effect (Shuit et al. 2010). Therefore, A, B, C, $\mathrm{AC}$ and $\mathrm{BC}$ terms play an important role in increasing the FAME yield whereas $\mathrm{A}^{2}, \mathrm{~B}^{2}, \mathrm{C}^{2}$ and $\mathrm{AB}$ had a negative effect that decrease the FAME yield.

Analysis of variance (ANOVA) was further carried out to determine the significance and the fitness of the quadratic model. The ANOVA for the response surface quadratic model was presented in Table 4. The Model F-value of 100.68 and Prob $>F$ of $<0.0001$ implied that the model was significant at $95 \%$ confidence level. The Prob $>$ F or p-value (probability of error value) is a tool used to determine the significance of each regression coefficient as well as interaction effect of each crossproduct. The smaller the $\mathrm{p}$-value, the bigger the significance of the corresponding coefficient is (Chen et al. 2008). In this case, the p-values less than 0.05 indicated that the particular term was statistically significant. From the ANOVA results, A, B, C, $\mathrm{A}^{2}, \mathrm{~B}^{2}, \mathrm{C}^{2}, \mathrm{AB}$ and $\mathrm{BC}$ were significant terms while $\mathrm{AC}$ was insignificant term in influence the FAME yield. The lack of fit F-value of 1.52 and p-value of 0.3529 (p-value $>0.05$ is not significant) implied the lack of fit is not significant relative to the pure error and the model is satisfactorily fitted to experimental data. The $\mathrm{R}^{2}$ value for the model was 0.9902 which means $99.02 \%$ of the total variation in the biodiesel yield was attributed to the experimental variables studied. The closer the $\mathrm{R}^{2}$ value to the unity, the better the model will be as the predicted yield and the actual yield were in reasonable agreement. The relationship can be illustrated by plotting the graph of predicted yield against experimental yield (Figure 2). A linear line was obtained, indicated that this model provided a good approximation to the experimental yields. 
TABLE 4. Analysis of variance (ANOVA) for response surface quadratic model

\begin{tabular}{|c|c|c|c|c|c|c|}
\hline Source & Sum of squares & $\begin{array}{l}\text { Degree of } \\
\text { freedom }\end{array}$ & Mean of square & F-value & Prob $>$ F & \\
\hline Block & 10.50 & 1 & 10.50 & & & \\
\hline Model & 13086.91 & 9 & 1454.10 & 100.68 & $<0.0001$ & Significant \\
\hline A & 4448.34 & 1 & 4448.34 & 308.00 & $<0.0001$ & \\
\hline B & 74.30 & 1 & 74.30 & 5.14 & 0.0495 & \\
\hline $\mathrm{C}$ & 534.42 & 1 & 534.42 & 37.00 & $<0.0002$ & \\
\hline A2 & 6660.68 & 1 & 6660.68 & 461.18 & $<0.0001$ & \\
\hline $\mathrm{B} 2$ & 87.72 & 1 & 87.72 & 6.07 & 0.0359 & \\
\hline $\mathrm{C} 2$ & 1022.23 & 1 & 1022.23 & 70.78 & $<0.0001$ & \\
\hline $\mathrm{AB}$ & 703.13 & 1 & 703.13 & 48.68 & $<0.0001$ & \\
\hline $\mathrm{AC}$ & 18.00 & 1 & 18.00 & 1.25 & 0.2932 & \\
\hline $\mathrm{BC}$ & 74.42 & 1 & 74.42 & 5.15 & 0.0494 & \\
\hline Residual & 129.98 & 9 & 14.44 & & & \\
\hline Lack of fit & 85.17 & 5 & 17.03 & 1.52 & 0.3529 & Not significant \\
\hline Pure error & 44.81 & 4 & 11.20 & & & \\
\hline Cor Total & 13227.40 & 19 & & & & \\
\hline $\begin{array}{l}\text { Standard deviation : } \\
\text { Mean : } \\
\text { Coefficient of variation: }\end{array}$ & $\begin{array}{r}3.80 \\
72.60 \\
\text { n: } 5.23\end{array}$ & $\begin{array}{l}\mathrm{R}^{2}: \\
\text { Adjusted } \mathrm{R}^{2} \text { : } \\
\text { Predicted } \mathrm{R}^{2}: \\
\text { Adequate precision: }\end{array}$ & $\begin{array}{r}0.9902 \\
0.9803 \\
0.9295 \\
32.4126\end{array}$ & & & \\
\hline
\end{tabular}

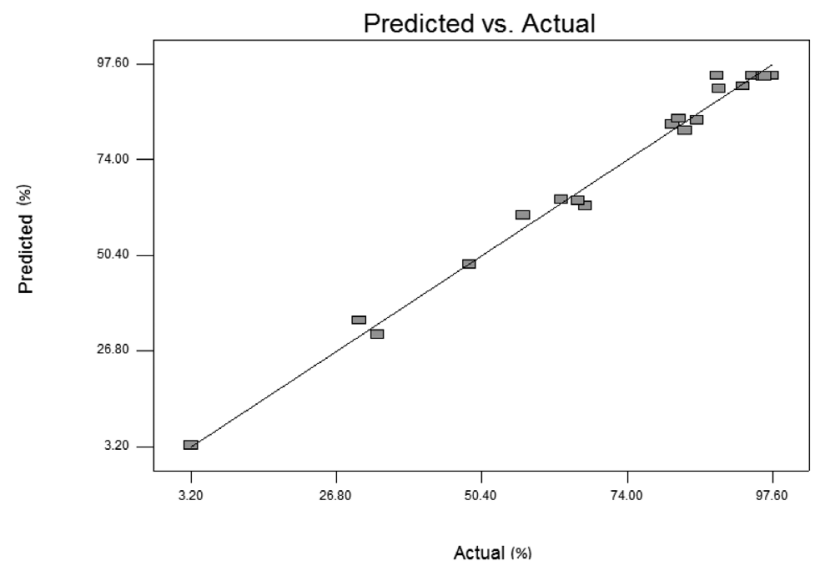

FIGURE 2. Predicted yield against actual (experimental) yield of palm oil methyl esters

\section{PARAMETER STUDY}

Figure 3(a) and 3(b) shows the contour plot and the threedimensional (3D) plot for the interaction effect between $\mathrm{A}$ : reaction time and $\mathrm{B}$ : catalyst loading. The reaction temperature and methanol to oil molar ratio were kept constant at $65^{\circ} \mathrm{C}$ and $12: 1$, respectively, throughout the experiments. The contour plot (Figure 3(a)) showed that higher biodiesel yield (>90\%) can be obtained between intermediate and high level of reaction time ( 2 to $3 \mathrm{~h}$ ) and between the investigated range of catalyst loading ( 2 to 4 wt. \%). The 3D respond surface showed that the biodiesel yield was increased with increasing reaction time and amount of catalysts. The significant increment of biodiesel yield (33 to $81 \%$ ) was observed when the reaction time was raised from low level $(1 \mathrm{~h})$ to high level $(3 \mathrm{~h})$ and at low level (2 wt. \%) of catalyst loading. Low biodiesel content at low reaction time might due to the mass transfer effect of the three-phase system (oil-methanol-catalyst). Immiscibility of oil and methanol leads to the diffusion limitation and thus lowering the rate of reaction. However, the high level of reaction time $(3 \mathrm{~h})$ and amount of catalyst (4 wt. \%) will lead to the decrease in biodiesel yield. After reaching the equilibrium, according to Le Chatelier's principle, further proceed of the transesterification may lead to the reverse of reaction to the reactant side and hence lowered the biodiesel yield. 
(a)

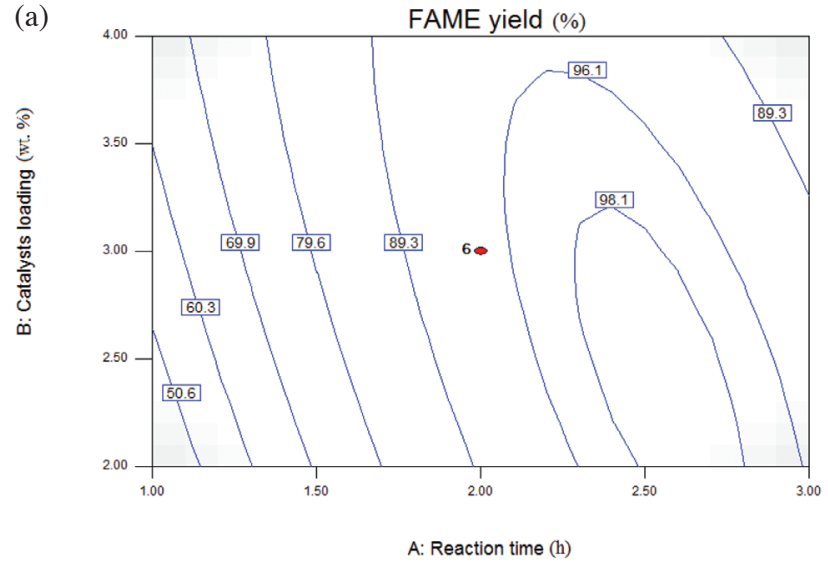

(b)

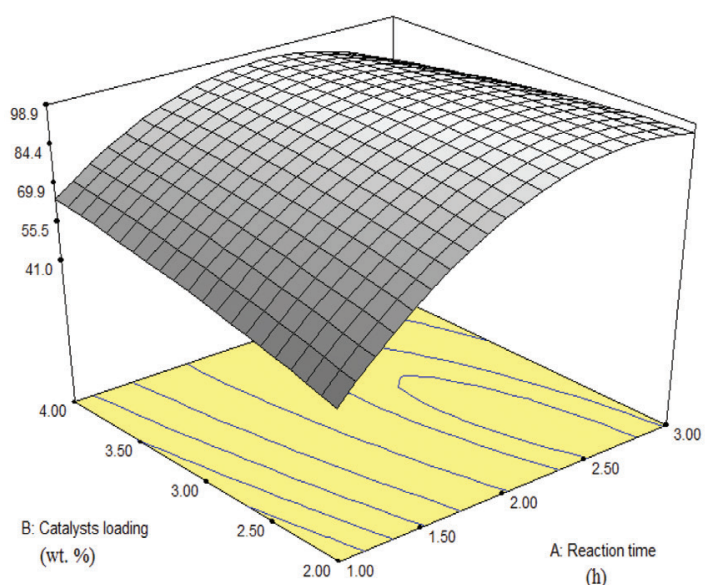

FIGURE 3(a) Contour plot and (b) three-dimensional response surface plot of biodiesel yield (effect of reaction time (A) and catalyst loading (B), methanol to oil molar ratio $=12: 1$, reaction temperature $=65^{\circ} \mathrm{C}$ )

The interaction effect of B: catalyst loading and C: methanol to oil molar ratio on FAME yield was shown in Figure 4(a) and 4(b). Meanwhile, reaction temperature and reaction time were fixed at $65^{\circ} \mathrm{C}$ and $2 \mathrm{~h}$, respectively. The contour plot (Figure 4(a)) showed that high biodiesel yield (>94\%) can be attained between intermediate to high level of catalyst loading (3 to $4 \mathrm{wt}$. \%) and methanol to oil molar ratio (12 to 15 ). The $3 \mathrm{D}$ surface response showed that the increment of methanol to oil molar ratio (from 9 to $12 \mathrm{wt}$. $\%$ ) increased the biodiesel yield from 79 to $90 \%$ at low level of amount of catalyst (2 wt. \%). Further increment of the methanol to oil molar ratio (from 12 to 15 ) leads to the drop of biodiesel yield. This might due to the excess methanol in the reaction mixture tends to increase the solubility of the glycerol, promoting glycerolysis reaction where glycerol reacts with the biodiesel to form back monoglyceride (Lin et al. 2009). At low level of methanol to oil molar ratio, the increase of catalyst amount has negligible effect on biodiesel yield. However, the biodiesel yield increased significantly (from 79 to $96 \%$ ) when both of the methanol to oil molar ratio and catalyst loading increased to the intermediate and high level. Intermediate and high level of methanol to oil molar ratio and catalyst loading may suggest that more active sites of catalyst are available to react with methanol and thus increase the reaction rate.

\section{OPTIMIZATION OF BIODIESEL PRODUCTION}

In biodiesel industry, relatively high product yields are always desired so that massive production is economical feasible. Thus, optimization study was carried out to obtain the optimum combination of operating conditions at which the maximum biodiesel yield is achieved. In this study, biodiesel yield was set to maximum value, while the other reaction parameters were set in a range between high and low levels as shown in Table 5. The experimental conditions with the highest predicted biodiesel yield were selected for further validation. The result of model validation was shown in Table 6 . The optimum biodiesel yield of $97.67 \%$ was obtained by transesterifying palm oil
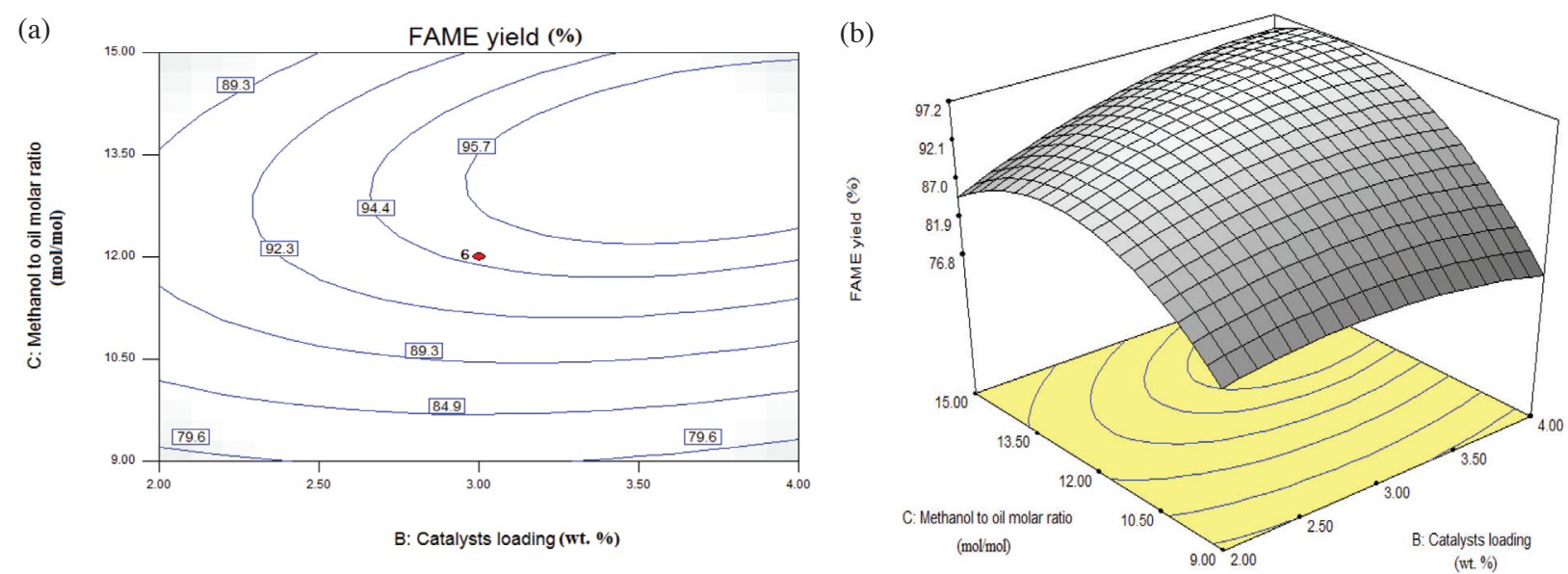

FIGURE 4 (a) Contour plot and (b) three-dimensional response surface plot of biodiesel yield (effect of catalyst loading (B) and methanol to oil molar ratio $(\mathrm{C})$, reaction time $=2 \mathrm{~h}$, reaction temperature $=65^{\circ} \mathrm{C}$ ) 
with $3.60 \mathrm{wt}$ \% $\%$ of catalysts and methanol to oil molar ratio of 13.04 at $65^{\circ} \mathrm{C}$ for $2.67 \mathrm{~h}$. The experimental yield was in good agreement with the predicted yield, with relatively small percentage error $(1.71 \%)$. This indicated that the proposed statistical model was suitable for prediction of optimized biodiesel yield and for optimization of transesterification process.

\section{CHARACTERIZATION OF CaO- $-\mathrm{Nb}_{2} \mathrm{O}_{5}$ CATALYST}

Thermal events of $\mathrm{CaO}-\mathrm{Nb}_{2} \mathrm{O}_{5}$ mixed oxide catalyst was depicted in Figure 5. Decomposition commenced at temperature 350 to $420^{\circ} \mathrm{C}$ was due to the removal of bonded water molecules from $\mathrm{Ca}(\mathrm{OH})_{2}$. The weight loss involved was $6.5 \%$. Second stage occurred at temperature range from 500 to $610^{\circ} \mathrm{C}$ with weight loss of $0.8 \%$. This was attributed to the decomposition of calcium carbonate $\left(\mathrm{CaCO}_{3}\right)$ into calcium oxide $(\mathrm{CaO})$ with the release of carbon dioxide $\left(\mathrm{CO}_{2}\right)$ as a by-product (Ngamcharussrivichai et al. 2008; Vujicic et al. 2010).

The XRD pattern of $\mathrm{CaO}-\mathrm{Nb}_{2} \mathrm{O}_{5}$ mixed oxide was shown in Figure 6. CaO (JCPDS file 37-1497) peaks were detected at $2 \theta$ of $32.2^{\circ}, 37.3^{\circ}$ and $53.8^{\circ}$ while $\mathrm{Nb}_{2} \mathrm{O}_{5}$ (JCPDS file 37-1468) was detected throughout the $2 \theta$ range of $10-60^{\circ}$. Besides, the XRD pattern also showed that $\mathrm{CaO}$ and $\mathrm{Nb}_{2} \mathrm{O}_{5}$ existed as separated metal oxide without the formation of binary phase, $\mathrm{CaNb}_{2} \mathrm{O}_{6}$. Elemental compositions and the surface area of the prepared catalyst were examined using X-ray fluorescence (XRF) and BET measurement, respectively. The results were shown in Table 7. The elemental compositions of the prepared catalyst were in good agreement with the theoretical value, with deviation less than $3 \%$. The BET surface area of the $\mathrm{CaO}, \mathrm{Nb}_{2} \mathrm{O}_{5}$ and $\mathrm{CaO}-\mathrm{Nb}_{2} \mathrm{O}_{5}$ mixed oxide catalysts were $4.8,6.0$ and $7.5 \mathrm{~m}^{2} / \mathrm{g}$, respectively. The improved surface area of $\mathrm{CaO}-\mathrm{Nb}_{2} \mathrm{O}_{5}$ mixed oxide may due to the homogeneous dispersion of $\mathrm{CaO}$ on the surface of $\mathrm{Nb}_{2} \mathrm{O}_{5}$.

The basicity strength of the catalysts was determined by using temperature-programmed desorption with $\mathrm{CO}_{2}$ as probe molecule (TPD- $\mathrm{CO}_{2}$ ). The TPD- $\mathrm{CO}_{2}$ profile of the $\mathrm{CaO}, \mathrm{Nb}_{2} \mathrm{O}_{5}$ and $\mathrm{CaO}-\mathrm{Nb}_{2} \mathrm{O}_{5}$ catalysts was depicted in Figure 7. The basicity of bulk $\mathrm{Nb}_{2} \mathrm{O}_{5}$ and $\mathrm{CaO}$ was expressed as 26.24 and $866.07 \mu \mathrm{mol} \mathrm{CO}_{2} / \mathrm{g}$ at the temperature range of $500-700^{\circ} \mathrm{C}$. Higher basicity $(1303.23 \mu \mathrm{mol} \mathrm{CO} / \mathrm{g})$ was shown by $\mathrm{CaO}-\mathrm{Nb}_{2} \mathrm{O}_{5}$ mixed oxide, compared with bulk $\mathrm{CaO}$ and $\mathrm{Nb}_{2} \mathrm{O}_{5}$ at the same temperature range. The increased basicity in $\mathrm{CaO}-\mathrm{Nb}_{2} \mathrm{O}_{5}$ mixed oxide may due to the synergic effect between metallic ion of $\mathrm{CaO}$ and $\mathrm{Nb}_{2} \mathrm{O}_{5}$.

TABLE 5. Optimization criteria for transesterification process

\begin{tabular}{lccc}
\hline Factors & Goal & Lower limit & Upper limit \\
\hline Reaction time & is in range & 1 & 3 \\
Catalyst loading & is in range & 2 & 4 \\
Methanol to oil molar ratio & is in range & 9 & 15 \\
FAME yield & maximize & 3.2 & 97.6 \\
\hline
\end{tabular}

TABLE 6. Result of model validation at the optimum conditions

\begin{tabular}{cccccc}
\hline $\begin{array}{c}\text { A:Reaction } \\
\text { time } \\
(\mathrm{h})\end{array}$ & $\begin{array}{c}\text { B:Catalyst } \\
\text { loading } \\
(\text { wt. } \%)\end{array}$ & $\begin{array}{c}\text { C:Methanol to oil } \\
\text { molar ratio } \\
(\mathrm{mol} / \mathrm{mol})\end{array}$ & $\begin{array}{c}\text { Experimental } \\
\text { yield } \\
(\%)\end{array}$ & $\begin{array}{c}\text { Predicted } \\
\text { yield } \\
(\%)\end{array}$ & $\begin{array}{c}\text { Percentage } \\
\text { error } \\
(\%)\end{array}$ \\
\hline 2.67 & 3.60 & 13.04 & 97.67 & 99.37 & 1.71 \\
\hline
\end{tabular}

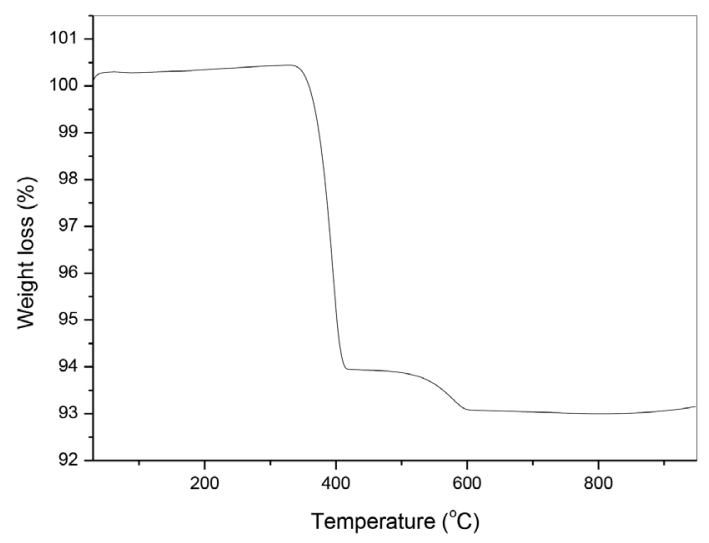

FIGURE 5. TGA thermograph of uncalcined $\mathrm{CaO}-\mathrm{Nb}_{2} \mathrm{O}_{5}$ mixed oxide catalyst 


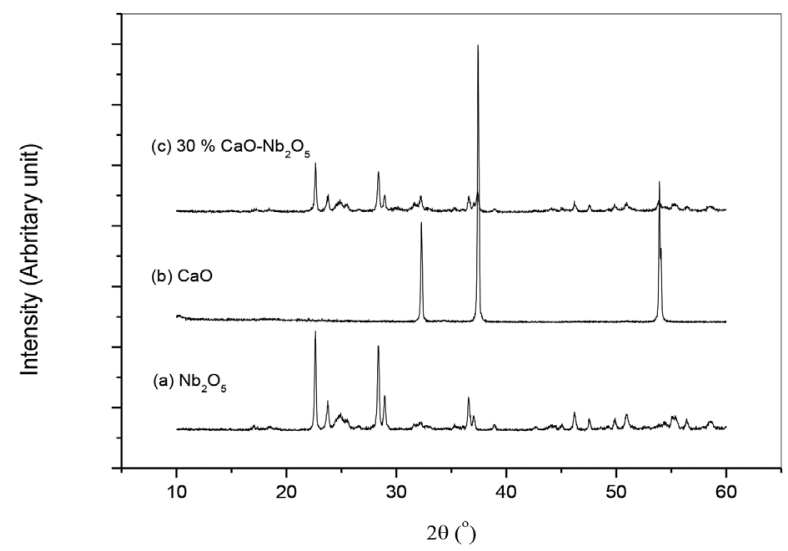

FIGURE 6. XRD pattern of the $\mathrm{CaO}-\mathrm{Nb}_{2} \mathrm{O}_{5}$ mixed oxide catalyst

TABLE 7. BET surface area and elemental compositions of $\mathrm{CaO}, \mathrm{Nb}_{2} \mathrm{O}_{5}$ and $\mathrm{CaO}-\mathrm{Nb}_{2} \mathrm{O}_{5}$ mixed oxides

\begin{tabular}{lccccc}
\hline \multirow{2}{*}{ Samples } & $\begin{array}{c}\text { Surface area } \\
\left(\mathrm{m}^{2} / \mathrm{g}\right)^{\mathrm{a}}\end{array}$ & \multicolumn{4}{c}{ Theoretical weight percent (wt. \%) } \\
\cline { 3 - 6 } & 4.8 & $\mathrm{CaO}$ & $\mathrm{Nb}_{2} \mathrm{O}_{5}$ & $\mathrm{CaO}$ & $\mathrm{Nb}_{2} \mathrm{O}_{5}$ \\
\hline $\mathrm{CaO}$ & 6.0 & - & - & - & - \\
$\mathrm{Nb}_{2} \mathrm{O}_{5}$ & 7.5 & 30.0 & - & - & - \\
$\mathrm{CaO} / \mathrm{Nb}_{2} \mathrm{O}_{5}$ & & 70.0 & 29.9 & 67.5 \\
\hline
\end{tabular}

Note:

${ }^{\text {a }}$ Determined from BET isotherm

${ }^{\mathrm{b}}$ From calculation

${ }^{\mathrm{c}}$ Determined by XRF

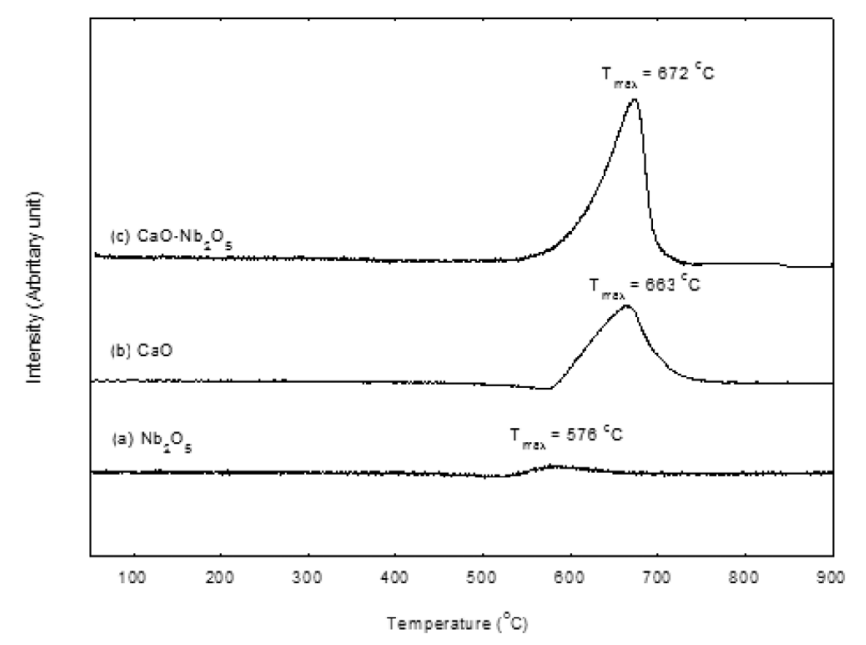

FIGURE 7. TPD-CO 2 profile for the $\mathrm{Nb}_{2} \mathrm{O}_{5}, \mathrm{CaO}$ and $\mathrm{CaO}-\mathrm{Nb}_{2} \mathrm{O}_{5}$ mixed oxide catalysts

\section{REUSABILITY AND LEACHING TEST}

After transesterification, the $\mathrm{CaO}-\mathrm{Nb}_{2} \mathrm{O}_{5}$ mixed oxide catalyst was separated from the product and reused in the subsequent reactions without further post-treatment. The reusability of $\mathrm{CaO}$ and $\mathrm{CaO}-\mathrm{Nb}_{2} \mathrm{O}_{5}$ mixed oxide catalyst was shown in Figure 8. It can be clearly seen that the catalytic activity of $\mathrm{CaO}$ decreased sharply from 95 to $75 \%$ after 4 runs. In comparison, $\mathrm{CaO}-\mathrm{Nb}_{2} \mathrm{O}_{5}$ mixed oxide catalyst can be reused up to 6 times with biodiesel yield more than $75 \%$. Dissolution of the fraction of bulk $\mathrm{CaO}$ into reaction medium was the factor contributed to the deactivation of catalyst (Gryglewicz 1999; Mootabadi et al. 2010). The result was further confirmed by the leaching test performed by using AAS (Table 8). The concentration of $\mathrm{CaO}$ detected in the biodiesel catalyzed by $\mathrm{CaO}$ was $270.6 \mathrm{ppm}$ whilst only $32.5 \mathrm{ppm}$ for $\mathrm{CaO}-\mathrm{Nb}_{2} \mathrm{O}_{5}$ mixed oxide catalyst. The dissolution of $\mathrm{CaO}$ from $\mathrm{CaO}-\mathrm{Nb}_{2} \mathrm{O}_{5}$ mixed oxide catalyst was much lower (about 9 folds lesser) than that of the bulk $\mathrm{CaO}$. The improved stability of $\mathrm{CaO}-\mathrm{Nb}_{2} \mathrm{O}_{5}$ mixed oxide catalyst can be related to the 


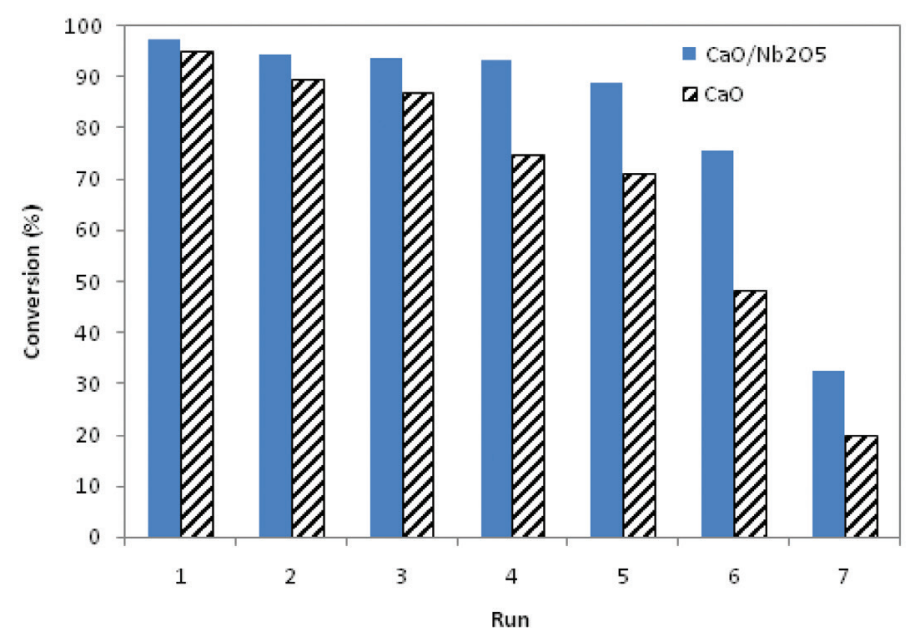

FIGURE 8 . Reusability of $\mathrm{CaO}$ and $\mathrm{CaO}-\mathrm{Nb}_{2} \mathrm{O}_{5}$ mixed oxide catalyst

TABLE 8. Dissolution of $\mathrm{CaO}$ and $\mathrm{Nb}_{2} \mathrm{O}_{5}$ from the catalyst into the products

\begin{tabular}{lcc}
\hline \multirow{2}{*}{ Catalysts } & \multicolumn{2}{c}{ Concentration of metal leaching (ppm) } \\
\cline { 2 - 3 } & $\mathrm{CaO}$ & $\mathrm{Nb}_{2} \mathrm{O}_{5}$ \\
\hline $\mathrm{CaO}$ & 270.6 & - \\
$\mathrm{CaO}-\mathrm{Nb}_{2} \mathrm{O}_{5}$ & 32.5 & - \\
\hline
\end{tabular}

strong synergic interaction between $\mathrm{CaO}$ and $\mathrm{Nb}_{2} \mathrm{O}_{5}$ metal oxides (Sohn \& Park 1997).

\section{CONCLUSION}

Response surface methodology with central composite design was successfully employed in studying the effects of various variables and optimization of biodiesel production. The optimum biodiesel yield of $97.67 \%$ was achieved under the optimum reaction conditions of 2.67 $\mathrm{h}$ reaction time, $3.60 \mathrm{wt}$. \% of catalyst and methanol to oil molar ratio 13.04 . The high biodiesel yield can be correlated to the high basicity of the catalyst. Besides, $\mathrm{CaO}-\mathrm{Nb}_{2} \mathrm{O}_{5}$ mixed oxide catalyst has better reusability than the bulk $\mathrm{CaO}$. The enhanced stability was due to the synergic interaction between $\mathrm{CaO}$ and $\mathrm{Nb}_{2} \mathrm{O}_{5}$ metal oxides. $\mathrm{CaO}-\mathrm{Nb}_{2} \mathrm{O}_{5}$ mixed oxide catalyst is a potential catalyst for biodiesel industry due to its strong basic strength and high performance in transesterification process.

\section{ACKNOWLEDGEMENTS}

The authors would like to express sincere gratitude to Universiti Putra Malaysia (UPM) and the Ministry of Science, Technology and Innovation (MOSTI), Malaysia via National Science Fellowship (NSF) for the financial support. Besides, the authors would like to acknowledge the IOI Group, Malaysia for providing the palm oil.

\section{REFERENCES}

Alamu, O.J., Waheed, M.A. \& Jekayinfa, S.O. 2008. Effect of ethanol-palm kernel oil ratio on alkali-catalyzed biodiesel yields. Fuel 87: 1529-1533.

Antunes, W.M., Veloso, C.O. \& Henriques, C.A. 2008. Transesterification of soybean oil with methanol catalyzed by basic solids. Catalysis Today 133-135: 548-554.

Arzamendi, G., Campoa, I., Arguinarena, E., Sanchez, M., Montes, M. \& Gandia, L.M. 2007. Synthesis of biodiesel with heterogeneous $\mathrm{NaOH} /$ alumina catalysts: Comparison with homogeneous $\mathrm{NaOH}$. Chem. Eng. J. 134: 123-130.

Bas, D. \& Boyacl, I.H. 2007. Modeling and optimization I: Usability of response surface methodology. Journal of Food Engineering 78: 836-845.

Bezerra, M.A., Santelli, R.E., Oliveira, E.P., Villar, L.S. \& Escaleira,L.A. 2008. Response surface methodology (RSM) as a tool for optimization in analytical chemistry. Talanta 76: 965-977.

Chen, X., Du, W. \& Liu, D. 2008. Response surface optimization of biocatalytic biodiesel production with acid oil. Biochemical Engineering Journal 40: 423-429.

Dmytryshyn, S.L., Dalai, A.K. \& Chaudhari, S.T. 2004. Synthesis and characterization of vegetable oil derived esters: Evaluation for their diesel additive properties. Bioresource Technology 98: 1724-1733.

Dorado, M.P., Ballesteros, E., Arnal, J.M., Gómez, J. \& López, F.J. 2003. Exhaust emissions from a diesel engine fueled with transesterifiedwaste olive oil. Fuel 82: 1311-1315.

Dennis Leung, Y.C., Wu, X. \& Leung, M.K.H. 2010. A review on biodiesel production using catalyzed transesterification. Applied Energy 87: 1083-1095. 
Fukuda, H., Kondo, A. \& Noda, H. 2001. Biodiesel fuel production by transesterification of oils. Journal of Bioscience Bioengineering 92: 405-416.

Gryglewicz, S. 1999. Rapeseed oil methyl esters preparation using heterogeneous catalysts. Bioresource Technology 70: 249-253.

Helwani, Z., Othman, M.R., Aziz, N., Fernando, W.J.N. \& Kim, J. 2009. Technologies for production of biodiesel focusing on green catalytic techniques: A review. Fuel Processing Technology 90: 1502-1514.

Kouzu, M., Yamasaka, S., Hidaka, J. \& Tsunomori, M. 2009. Heterogeneous catalysis of calcium oxide used for tranesterification of soybean oil with refluxing methanol. Applied Catalysis A: General 355: 94-99.

Lin, C.Y., Lin, H.A. \& Hung, L.B. 2006. Fuel structure and properties of biodiesel produced by peroxidation process. Fuel 85: 1743-1749.

Lin, L., Ying, D., Chaitep, S. \& Vittayapadung, S. 2009. Biodiesel production from crude rice bran oil and properties as fuel. Applied Energy 86: 681-688.

Liu, X., He, H., Wang, Y., Zhu, S. \& Piao, X. 2008. Transesterification of soybean oil to biodiesel using $\mathrm{CaO}$ as a solid base catalyst. Fuel 87: 216-221.

Montgomery, D.C. 2001. Design and Analysis of Experiments. 5th ed. New York: John Willy and Sons.

Mootabadi, H., Salamatinia, B., Bhatia, S. \& Abdullah,A.Z. 2010. Ultrasonic-assisted biodiesel production process from palm oil using alkaline earth metal oxides as the heterogeneous catalysts. Fuel 89: 1818-1825.

Ngamcharussrivichai, C., Totarat, P. \& Bunyakiat, K. 2008. Ca and $\mathrm{Zn}$ mixed oxide as a heterogeneous base catalyst for transesterification of palm kernel oil. Applied Catalysis A: General 341: 77-85.

Sharma, Y.C., Singh, B. \& Korstad, J. 2011 . Latest development on application of heterogeneous basic catalysts for an efficient and eco-friendly synthesis of biodiesel: A review. Fuel 90: 1309-1324.
Sharma, Y.C., Singh, B. \& Upadhyay, S.N. 2008. Advancement in development and characterization of biodiesel: A review. Fuel 87: 2355-2373.

Shuit, S.H., Lee, K.T., Kamaruddin, A.H. \& Yusup, S. 2010. Reactive extraction of jatropha curcas L. seed for production of biodiesel: Process optimization study. Environmental Science \& Technology 44: 4361-4367.

Sohn, J. \& Park, E. 1997. Acidic properties of $\mathrm{CaO}-\mathrm{SiO}_{2}$ binary oxide catalyst and activity for acid catalysis. Korean Journal of Chemical Engineering 14: 192-197.

Vujicic, Dj., Comic, D., Zarubica, A., Micic, R. \& Boskovic, G. 2010. Kinetics of biodiesel synthesis from sunflower oil over $\mathrm{CaO}$ heterogeneous catalyst. Fuel 89(8): 2054-2061.

West, A.R. 1999. Basic Solid State Chemistry. 2nd ed. Chichester: John and Sons.

Wong, Y.C., Tan, Y.P., Taufiq-Yap, Y.H. \& Ramli, I. 2014. Effect of calcination temperatures of $\mathrm{CaO} / \mathrm{Nb}_{2} \mathrm{O}_{5}$ mixed oxide catalysts on biodiesel production. Sains Malaysiana 43(5): 783-790.

Centre of Excellence for Catalysis Science and Technology

Universiti Putra Malaysia

43400 UPM Serdang, Selangor Darul Ehsan

Malaysia

Department of Chemistry, Faculty of Science

Universiti Putra Malaysia

43400 UPM Serdang, Selangor Darul Ehsan

Malaysia

*Corresponding author; email: typ@upm.edu.my

Received: 22 November 2013

Accepted: 8 August 2014 